DOI : $10.14746 /$ pp.2014.19.4.9

\title{
Michał TOMCZYK
}

Lucerna, Szwajcaria

\section{Proces decyzyjny jako istotny element analizy zjawisk integracyjnych w Europie z perspektywy teoretycznej. Przykład Szwajcarii}

\begin{abstract}
Streszczenie: Od wielu lat prowadzony jest dyskurs naukowy, dążący do ujęcia zjawisk integracyjnych w Europie w teoretyczne ramy. Wielu badaczy, zajmujących się tworzeniem modeli rozwoju współpracy międzynarodowej sugeruje przeniesienie analizy z poziomu systemu na poziom poszczególnych państw, celem lepszego uzasadnienia motywów integracji oraz jej zróżnicowanych form. Z kolei zrozumienie zachowania państwa na arenie międzynarodowej, w tym działań podjętych wobec innych aktorów - państw lub organizacji, na płaszczyźnie bilateralnej lub multilateralnej nie jest możliwe bez wyjaśnienia natury i charakteru procesów decyzyjnych. Niniejszy artykuł jest więc próbą zwrócenia uwagi na proces decyzyjny, jako istotnego elementu analizy procesów integracyjnych w Europie. Co więcej, punktem odniesienia jest Szwajcaria, formalnie nienależąca do UE, ale silnie z nią zintegrowana, głównie na bazie powiązań bilateralnych. Zaprezentowana charakterystyka procesu decyzyjnego w kraju niebędącego członkiem Wspólnoty pokazuje, jakie elementy należałoby brać pod uwagę, analizując zachowanie państw na arenie międzynarodowej oraz dlaczego właściwa jego analiza może posłużyć wyjaśnieniu alternatywnych form integracji europejskiej, stanowiąc tym samym przyczynek do dyskusji nad jej teoretycznymi aspektami.
\end{abstract}

Słowa kluczowe: integracja europejska, Szwajcaria, proces decyzyjny, polityka zagraniczna

$\mathbf{P}$ odstawowe teorie stosunków międzynarodowych - liberalizm i realizm pozwalają na zrozumienie i właściwe zinterpretowanie określonych zachowań państw w stosunkach międzynarodowych. Pomimo istnienia kilku różnic interpretacyjnych, charakterystycznych dla indywidualnych badaczy, którzy zajmują się ową tematyką, należy zwrócić uwagę na kilka podstawowych zasad, przyświecających obu szkołom. Przykładowo, podstawowym założeniem realizmu jest, iż państwa funkcjonujące w anarchii dążą do maksymalizacji własnej potęgi i bezpieczeństwa (Morgenthau, 2005; Waltz, 1979). Dlatego polityka międzynarodowa jest nieustanną walką o władzę i dominację. Kluczowe znaczenie ma tutaj struktura systemu, która nijako wymusza na państwach, z uwagi na ciągłe poczucie zagrożenia, dążenie do zdobycia przewagi, ewentualnie równowagi między aktorami stosunków międzynarodowych. Z kolei liberalizm podkreśla wagę współpracy międzynarodowej jako niezbędnego elementu zapewnienia państwu stabilizacji, bezpieczeństwa i ekonomicznego rozwoju. Państwa dążą do ograniczenia niepewności w relacjach zewnętrznych, działają na rzecz dobra wspólnego i przestrzegają wspólnie ustalonych norm i zasad. Widać to chociażby w przypadku integracji europejskiej, bazującej przecież na różnych formach współpracy międzyrządowej lub ponadnarodowej, w ramach której państwa zmuszone są do zawierania kompromisów i negocjacji. Oczywiście 
dyskusja polityczna na temat modelu integracji europejskiej znalazła swoje odzwierciedlenie $\mathrm{w}$ osobnych modelach teoretycznych. Wśród licznych interpretacji politologicznych warto wymienić chociażby teorię funkcjonalizmu i neofunkcjonalizmu, choć obie nawiązują w wielu aspektach do liberalnej myśli stosunków międzynarodowych (Moravcsik, 1993).

Próba wytłumaczenia określonego działania państw na arenie międzynarodowej, na bazie dostępnych teorii nie zawsze przynosi takie same rezultaty. Najczęściej związane jest to z odmienną interpretacją określonych zachowań i postaw ${ }^{1}$. Należy zauważyć, iż ma to ścisły związek z głębokością czy poziomem analizy określonych działań. Dlatego też wielu badaczy sugeruje przeniesienie badań z poziomu państw na poziom jednostek, biorących udział w podejmowaniu określonych decyzji (Byman, Pollack 2001, s. 107-146).

Zrozumienie zachowania państwa na arenie międzynarodowej, w tym działań podjętych wobec innych aktorów - państw lub organizacji, na płaszczyźnie bilateralnej lub multilateralnej nie jest zatem możliwe bez wyjaśnienia natury i charakteru procesów decyzyjnych. Polityka zagraniczna państw, za wyjątkiem niektórych o ustrojach niedemokratycznych, jest efektem łańcucha określonych procesów, składających się z kolektywnego współdziałania różnych podmiotów, na wielu poziomach organizacyjnych. Jest również uzależniona od szeregu czynników i determinantów - obiektywnych lub subiektywnych.

Polityka wewnętrzna i zewnętrzna wzajemnie się przenikają. Procesy zachodzące na poziomie krajowym, uwarunkowania polityczne, stosunki i zależności społeczne mają ogromny wpływ na postawę aktorów biorących udział w podejmowaniu decyzji politycznych.

Dodać do tego należy również określone światopoglądy i koncepcje stosunków międzynarodowych, stereotypy, uprzedzenia itp. decydentów politycznych, które bez wątpienia mają duży wpływ na ostateczny kształt podjętych przez dane państwo działań i ich zachowania na arenie międzynarodowej ${ }^{2}$. Nie ulega wątpliwości, iż wiele wydarzeń interpretowanych jest przez poszczególne jednostki na bazie określonych oczekiwań (Voss, Dorsey, 1992). Należy przy tym pamiętać, iż ich światopogląd, nawet jeżeli daje się zdefiniować, nie może w pełni posłużyć do wyjaśnienia pewnych działań lub zaniechań wówczas, gdy w procesie podejmowania decyzji uczestniczy wiele podmiotów, które zawsze są od siebie wzajemnie zależne. Może on natomiast, a nawet powinien być wykorzystany jako jeden z czynników, do zrozumienia i przewidywania zachowania określonego państwa i jego przywódców.

Polityka zagraniczna nie może też być zrozumiana bez uwzględnienia fazy implementacyjnej, która w wielu przypadkach może różnić się od początkowych koncepcji politycznych, zawartych chociażby w strategicznych dokumentach rządowych. Różnice pomiędzy koncepcją a praktyką polityczną są doskonałym dowodem na wagę oraz

${ }^{1}$ Przykładowo polityka USA była analizowana zarówno na bazie teorii liberalnej (Layne, Schwarz 1993, s. 5-23), neo-Wilsonizmu (Mearsheimer, 1995) jak i teorii realizmu, zwłaszcza w okresie zimnej wojny.

${ }^{2}$ Na przykład, członkowie administracji Reagana w połowie 1980 roku uważali, że współpraca z Sowietami przyniosłaby więcej szkód niż korzyści (Jervis, 1988, s. 326). 
złożoność procesów decyzyjnych i oddziaływania na nich określonych czynników, które sprawiają, iż realizacja początkowych intencji i planów decydentów politycznych nie zawsze jest możliwa.

W kontekście wyżej wymienionych zagadnień ciekawym obiektem badań mogą być procesy integracyjne w Europie. Wielokrotnie dyskutowane modele skupiają się na interpretacji zachowań i decyzji państw, celem wyjaśnienia motywów i sił napędowych integracji europejskiej. Za ich pomocą próbuje się zatem odpowiedzieć na pytanie czy mają one głównie charakter polityczny, związany z chęcią ustanowienia trwałego pokoju i bezpieczeństwa czy ekonomiczny, podyktowany dążeniem do zapewnienia stabilnego rozwoju gospodarczego, opartego na liberalizacji rynków? Istotne jest zatem w tym kontekście pytanie czy procesy integracyjne są zjawiskiem oddolnym, inspirowanym przez całe społeczeństwa czy też elity polityczne lub określone grupy interesu? Odpowiedź na to pytanie umożliwia analiza przytoczonych już wyżej procesów decyzyjnych. Poznanie motywów integracyjnych skłania z kolei do podjęcia próby znalezienia odpowiedzi na pytanie dotyczące dalszego ich rozwoju. Czy istnieje logiczna sekwencja przechodzenia przez kolejne formy i etapy integracji i w związku z tym czy możemy przewidzieć punkt końcowy, do którego zmierza Europa ${ }^{3}$. Co z kolei prowadzi do poszukiwania najbardziej efektywnego i optymalnego modelu integracji, pozwalającego na pogodzenie różnic ekonomicznych i politycznych pomiędzy państwami, ich zróżnicowanych aspiracji oraz wizji współpracy (Stubb, 1996; Gillespie, 1996). Jest to szczególnie istotne w kontekście poszerzającej się Wspólnoty, obejmującej znacznie bardziej zróżnicowane pod wieloma względami państwa. Wreszcie, dostępne teorie pomagają w zrozumieniu mechanizmów tworzenia instytucji ponadnarodowych. Kluczowe znaczenie w tej kwestii ma odpowiedź na pytanie czy ich podstawąjest wspólnota społeczno-psychologiczna, wspólna europejska tożsamość i solidarność? Kolejne kryzysy i spory, z którymi mamy do czynienia w ramach UE skłaniają do podważenia tych ostatnich ${ }^{4}$.

Teoretyczne analizy procesów integracyjnych dotyczą zazwyczaj państw, będących członkami Unii Europejskiej bądź aspirujących do takiego statusu. Przykładowo przedmiotem badań są często oddziaływania europeizacji na ich system polityczny bądź społeczny (Fisher, Sciarini, 2013; Fischer, Nicolet, Sciarini, 2002, s. 143-170). Interesującym zadaniem badawczym byłaby jednak analiza relacji między Wspólnotą a państwem niespełniającym żadnych z powyższych kryteriów. Co więcej, podejmująca próbę ujęcia integracji europejskiej nie tyle z punktu widzenia motywów i natury samych procesów, lecz z perspektywy państwa trzeciego, formalnie nienależącego do Wspólnoty, zwracając szczególną uwagę na specyfikę procesu decyzyjnego.

Szwajcaria, choć silnie zintegrowana z UE, pozostaje nadal poza jej strukturami i nie aspiruje do członkostwa ${ }^{5}$. Wzajemna współpraca oparta jest na szeregu umów bilateral-

\footnotetext{
${ }^{3}$ Wokół tego problemu koncentrują się rozważania funkcjonalistów i federalistów.

${ }^{4}$ Juan Diez Medrano proponuje rozdzielenie pojęcia kryzysu i sporu. Ten ostatni, będący w istocie różnicą zdań i koncepcji dotyczących formy integracji jest charakterystyczny musi być charakterystyczny dla organizacji skupiającej tak wiele zróżnicowanych pod względem politycznym i gospodarczym państw. Zob. Medrano (2012).

${ }^{5}$ Wniosek akcesyjny został co prawda złożony w 1992 roku, ale po negatywnym wyniku referendum w sprawie włączenia Szwajcarii do EOG został zamrożony na czas nieokreślony.
} 
nych, regulujących kooperację w kluczowych obszarach, obejmujących głównie handel, ale również problematykę bezpieczeństwa, dostępu do rynku pracy czy badań i rozwoju. Należy jednak zwrócić uwagę, iż ma ona charakter bezprecedensowy. Co prawda inne państwa, jak Norwegia czy Lichtenstein również zdołały wypracować dość silne więzi ze Wspólnota. W obu przypadkach jednak forma współpracy nie ma takiego samego charakteru jak w przypadku Szwajcarii ${ }^{6}$. Można zatem postawić tezę, iż z uwagi na chociażby silne powiązania normatywne (łącznie zawarto już ponad 100 umów dwustronnych) oraz wysoki stopień eurokompatybilności szwajcarskiego prawodawstwa współpracę między Szwajcarią a Unią Europejską możemy uznać za jedną z form integracji europejskiej. Co pozostaje szczególnie interesujące w kontekście aktualnej debaty nad formą i kształtem procesów integracyjnych, w kontekście zmieniających się uwarunkowań geopolitycznych oraz rosnącej liczby państw członkowskich.

Próba ujęcia relacji między Szwajcarią a Unią Europejską w teoretyczne ramy nie jest możliwa bez przeanalizowania motywów politycznych i gospodarczych, być może również społecznych, które przemawiały za taką współpracą. Rzetelna odpowiedź na to pytanie wymaga przeanalizowania procesów decyzyjnych w polityce zagranicznej Szwajcarii. Poczynając od koncepcji politycznych, przez wskazanie najważniejszych uwarunkowań i determinantów, na implementacji kończąc. Przedstawienie wyłącznie określonych działań, bez dogłębnej analizy ich motywów i uwarunkowań nie jest bowiem wystarczająca do postawienia rzetelnych wniosków co do istoty dwustronnych relacji. Jedynie pełna analiza procesów decyzyjnych umożliwia umieszczenie tej formy integracji z UE we właściwych ramach teoretycznych, tj. z perspektywy teorii stosunków międzynarodowych. Z uwagi na zbyt szeroki zakres takowych badań i ograniczeniami objętościowymi w przedmiotowej publikacji, niniejszy tekst stanowi jedynie próbę zasygnalizowania wagi i złożoności procesu decyzyjnego $\mathrm{w}$ analizie teoretycznych podstaw polityki zagranicznej państwa. Artykuł ten stanowi zatem przyczynek do dyskusji nad teoretycznymi aspektami zjawisk integracyjnych. Pogłębienie zasygnalizowanych tutaj problemów badawczych może stanowić cenny element dyskursu naukowego nad przyszłym lub docelowym, a więc najbardziej optymalnym kształtem zjednoczonej Europy.

\section{Procesy decyzyjne w polityce zagranicznej Szwajcarii}

Proces podejmowania decyzji ma w przypadku Szwajcarii bardzo złożony charakter. Podobnie jak w innych państwach mamy tutaj do czynienia z kilkoma etapami, z których każdy poddawany jest różnorakim oddziaływaniom i nacechowany różnymi zależnościami. Określone decyzje nie są bowiem podejmowane, a następnie implementowane przez wąską grupę decydentów. W przypadku Szwajcarii Rady Związkowej (rząd) bądź Departamentu Spraw Zagranicznych. Mogą być co najwyżej inicjowane, choć i ta faza niekoniecznie może mieć charakter autonomiczny. To co jednak w sposób szczególny odróżnia procesy decyzyjne w Szwajcarii to fakt silnej partycypacji społecznej, rozumianej jako możliwość oddziaływania obywateli czy określonych grup interesu na poszczególne

\footnotetext{
${ }^{6}$ Zarówno Norwegia, jak i Lichtenstein należą do Europejskiego Obszaru Gospodarczego i Schengen.
} 
fazy decydowania politycznego. Nie tylko poprzez klasyczne instrumenty demokracji bezpośredniej, jak referendum czy inicjatywa, z czym najczęściej asocjuje się szwajcarski system polityczny. Lecz również poprzez konsultacje społeczne na etapie przedparlamentarnym, mającym kluczowe znaczenie dla dalszego przebiegu procesu decyzyjnego. Jest to zresztą element charakterystyczny dla demokracji konsensualnej bądź negocjacyjnej (Kriesi, 2008, s. 115), mianem której najczęściej określa się ustrój Szwajcarii (Linder, 1999, s. 24-27; Rhinow, Huber-Hotz, 1996, s. 16).

Proces podejmowania określonej decyzji na poziomie federalnym możemy podzielić na kilka etapów. Zazwyczaj obejmuje on (Deleon, 1999; Heritier, 1994):

— ustalanie harmonogramu lub inicjację;

- fazę przygotowawczą, przedparlamentarną;

- fazę parlamentarna;

— fazę demokracji bezpośredniej;

- fazę realizacji/implementacji.

Ocenia się, iż podjęcie określonej decyzji, liczonej od momentu stworzenia pierwszego projektu aktu legislacyjnego do jego przyjęcia i implementacji ( $\mathrm{tj}$. w momencie umieszczenia jej w Dzienniku Ustaw) może trwać ok. 3 lat, co wydaje się okresem dość długim. Jednak w ostatnim czasie możemy zauważyć tendencję do skrócenia tego procesu, chociażby poprzez ograniczenie liczby aktów legislacyjnych, przesyłanych do konsultacji społecznych?

Szczególną wagę należałoby nadać fazie przedparlamentarnej. W jej trakcie przeprowadzany jest proces konsultacji, do których zapraszane są wszystkie grupy interesu, eksperci, przedstawiciele kantonów i partii politycznych. Jej zadaniem jest zatem wypracowanie najbardziej zadowalającego wszystkie strony konsensusu. Dążenie do uwzględnienia różnych punktów widzenia wynika z doświadczeń historycznych Szwajcarii i jej heterogeniczności, obejmującej różne grupy językowe, wyznaniowe, światopoglądowe (Neidhart, 1970). Faza przedparlamentarna ma więc na celu minimalizację kontrowersji na dalszych etapach, w szczególności na forum parlamentu. Teoretycznie zatem wypracowany w fazie przedparlamentarnej akt legislacyjny, zaakceptowany przez większość, może liczyć na przychylną recepcję w trakcie debaty parlamentarnej. Dostępne badania wskazują jednak, iż kontrowersyjna ustawa, nawet jeżeli została uzgodniona na etapie przedparlamentarnym, pozostaje taką we wszystkich kolejnych fazach. Zwiększa się również prawdopodobieństwo poddania jej pod głosowanie referendalne, którego wynik ma kluczowe znaczenie dla całego przebiegu procesu decyzyjnego.

Faza przedparlamentarna jest szczególnie istotna także z punktu widzenia niniejszej analizy, albowiem umożliwia zbadanie, które grupy społeczne i polityczne miały największy wpływ na kształt negocjacji, a więc również jaka była ich pozycja i rola w całym procesie. Fakt ten potwierdza również wcześniejszą konstatację, iż każda propozycja, przedstawiona przez władze może ulec większym bądź mniejszym modyfikacjom w zależności od pozycji i rodzaju określonej grupy społecznej. Oznacza to zatem, iż początkowa koncepcja polityczna nie zawsze możliwa jest do zrealizowania w praktyce.

\footnotetext{
${ }^{7}$ Umożliwia to zresztą nowe prawo, obowiązujące od marca 2005 roku. Zob. Bundesgesetz über das Vernehmlassungsverfahren (Vernehmlassungsgesetz VIG).
} 
Przykładowo chęć wprowadzenia określonej modyfikacji prawa pracy musi być skonfrontowana ze stanowiskiem związków zawodowych, które mogą co prawda wyrazić zgodę, ale za cenę określonych kompensacji.

Widoczne jest to w szczególności w kontekście polityki zagranicznej. Umowa międzynarodowa nie może być bowiem przedmiotem negocjacji i modyfikacji na poziomie krajowym. W tym przypadku aktorzy procesu decyzyjnego konfrontowani są jedynie z możliwościa jej akceptacji lub odrzucenia w całości. Bez możliwości ingerowania w zawartość merytoryczną. Pozorne ograniczenie przybliża jednak perspektywę zawetowania całej umowy, co nadaje konsultacjom społecznym znacznie ostrzejszego wymiaru i większego znaczenia niż w przypadku całkowicie negocjowalnego aktu prawa krajowego. Widoczne to było chociażby w przypadku umowy o swobodzie przepływu osób, kiedy to rząd zmuszony był do zaoferowania związkom zawodowym określone kompensacje w postaci instrumentów ochronnych (okresów przejściowych) w zamian za poparcie umowy na etapie przedparlamentarnym (Fischer, 2003). Jest to zresztą jeden z aspektów zjawiska internacjonalizacji procesu decyzyjnego w Szwajcarii, który był już przedmiotem licznych badań (Fischer, 2005).

Ponieważ w przypadku Szwajcarii, w przeciwieństwie chociażby do USA, większość decyzji nie jest podejmowana przez pojedyncze osoby, lecz zawsze w ramach złożonej organizacji (politycznej bądź społecznej), nie możemy rozważać i analizować określonych decyzji oraz decydentów w kategoriach homogenicznego bytu, kierującego się zawsze racjonalnymi przesłankami. Państwo w takim wypadku nie może być traktowane w kategoriach jednolitego i racjonalnego aktora (rational unitary actor). To prowadziłoby do znacznego uproszczenia całego procesu, czego wynikiem mogłoby być wyciagnięcie błędnych lub zbyt powierzchownych wniosków dotyczących zachowania Szwajcarii wobec omawianych w niniejszym tekście zjawisk integracyjnych. Celem właściwego zobrazowania problemu warto posłużyć się poniższą grafiką. Przedstawia ona podstawowy schemat procesu podejmowania decyzji, który może być zastosowany wobec praktycznie każdego państwa na świecie. W dużym uproszczeniu składa on się z 3 podstawowych elementów, które w niniejszym tekście nazwano - wydarzenie, państwo, decyzja (Schnur, 2000, s. 13).

Wykres 1. Podstawowy schemat procesu decyzyjnego

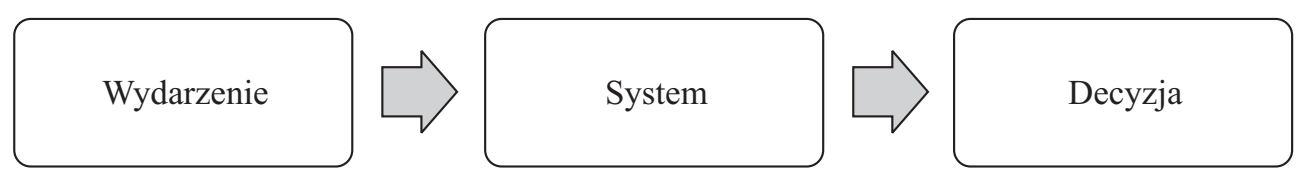

Źródło: Opracowanie własne na podstawie Schnur (2000, s. 13).

Decyzje państwa, jako podmiotu stosunków międzynarodowych, stanowią reakcję na określone bodźce (wydarzenia). To w jaki sposób państwo na nie zareaguje, zależy od szeregu uwarunkowań. Można by tutaj wymienić chociażby czynniki ekonomiczne, geograficzne, militarne, polityczne itp. Im bardziej jednak struktury państwa (system) są złożone, tym ostatecznie podejmowane decyzje stanowią efekt bardziej skomplikowanego procesu, w którym udział biorą różne podmioty. Te ostatnie również są obiektem od- 
działywania różnych czynników, które w mniejszym lub większym stopniu wpływają na ich zachowanie (decyzje). Mając zatem na uwadze specyfikę procesu decyzyjnego w Szwajcarii wyżej zarysowany schemat należałoby uszczegółowić, uwzględniając poszczególnych aktorów, którzy składają się na cały system (państwo).

\section{Wykres 2. Podstawowy schemat procesu decyzyjnego w Szwajcarii}

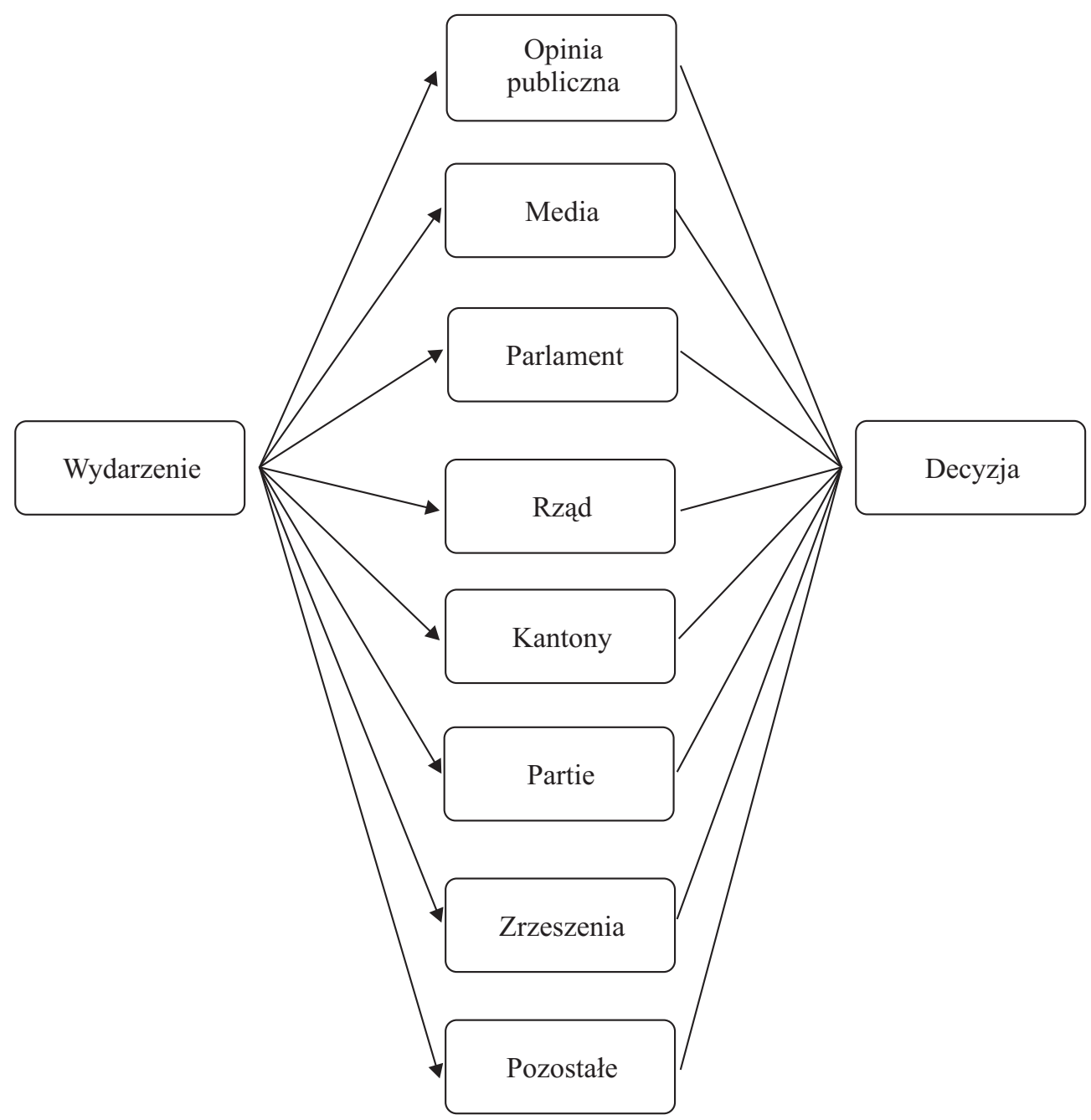

Źródło: Opracowanie własne na podstawie Schnur (2000, s. 13).

Powyższy schemat doskonale obrazuje mnogość aktorów procesu, która sprawia, iż ostateczne działania państwa nie są w istocie jednostkową reakcją na określone wydarzenie, lecz sumą reakcji poszczególnych podmiotów, które wchodzą w skład systemu. W praktyce zatem wpływ poszczególnych aktorów na określone decyzje polityczne jest ograniczony, tym bardziej, iż są oni w dużym stopniu od siebie uzależnieni. Dlatego ana- 
liza decyzji państwa w polityce zagranicznej musi być wielowymiarowa i uwzględniać pozycję i rolę poszczególnych aktorów i ich wzajemne oddziaływanie.

Polityka zagraniczna prowadzona jest na szczeblu federalnym ${ }^{8}$. Zgodnie z konstytucją odpowiedzialny jest za nią rząd, czyli Rada Związkowa ${ }^{9}$. Podział kompetencji ma tutaj charakter wertykalny, podobnie jak $\mathrm{w}$ innych państwach federalnych, takich jak Niemcy lub Austria (Goetschel, Bernath, Schwarz 2002, s. 60). Zadania Rady Związkowej w tym zakresie określone są szczegółowo w konstytucji $1^{10}$. Sprowadzają się one do stwierdzenia, iż rząd reprezentuje państwo na zewnątrz i określa cele oraz środki polityki zagranicznej. Wszystkie decyzje dotyczące zarządzania państwem, w tym również w obszarze relacji zewnętrznych, podejmowane są wspólnie przez wszystkich członków Rady Związkowej, gdyż w realizację polityki zagranicznej zaangażowane są różne Departamenty, nie tylko Spraw Zagranicznych (EDA). Rząd podejmuje zatem decyzje wspólnie, oczywiście na poziomie strategicznym, a nie operacyjnym. Choć pełni rolę koordynacyjną w całej fazie przedparlamentarnej procesu decyzyjnego. Szczególna pozycja egzekutywy wynika oczywiście z konieczności szybkiego reagowania na określone wydarzenia w polityce międzynarodowej, do czego, przynajmniej teoretycznie, Rada Związkowa poprzez podlegające jej Departamenty (ministerstwa) jest zdolna, mając tu na względzie zasoby kadrowe i możliwość szybkiego pozyskiwania niezbędnych informacji (Schnur, 2000, s. 76). Trzeba jednakże pamiętać, iż poszczególne resorty kierują się własnymi interesami i celami, co może doprowadzić do konfliktu pomiędzy poszczególnymi członkami Rady Związkowej w trakcie wypracowania wspólnego stanowiska. Tym bardziej, iż w dobie postępującej globalizacji oraz internacjonalizacji w zasadzie każdy aspekt funkcjonowania państwa ma swój wymiar międzynarodowy (Schnur, 2000, s. 86). Oczywiście dogłębna analiza decyzji podejmowanych w ramach Rady Związkowej powinna uwzględniać także inne elementy, jak chociażby aspekt subiektywnego postrzegania problematyki międzynarodowej poszczególnych członków rządu, przynależności partyjnej czy ich pozycji politycznej. Mając jednakże na względzie, iż decyzje podejmowane są przez Radę w sposób kolegialny i na zasadzie konsensusu można potraktować procesy decyzyjne na nieco większym poziomie ogólności. Tym bardziej, iż ograniczony dostęp do informacji w tym zakresie - stenogramy lub inne dokumenty z posiedzeń Rady nie są upubliczniane - uniemożliwia przeprowadzenie wyczerpujących i bardziej szczegółowych badań.

W większości wypadków istotną rolę w procesie decyzyjnym odgrywa również parlament, choć w praktyce jego faktyczne kompetencje i oddziaływanie uległy w ostatnim czasie ograniczeniu (Kriesi, Trechsel, 2008, s. 119, 120), o czym była już mowa wcześniej. Przede wszystkim w odniesieniu do możliwości inicjowania i współkształtowania decyzji politycznych. Widać to szczególnie w obszarze polityki zagranicznej, co jest efektem oddziaływania europeizacji na procesy decyzyjne, a zwłaszcza pozycji posz-

\footnotetext{
${ }^{8}$ Co prawda poszczególne kantony mają prawo do prowadzenia tzw. małej polityki zagranicznej, jednakże wyłącznie w odniesieniu do identycznych jednostek państwowych w innych krajach (np. niemieckich landów) oraz przy uwzględnieniu celów i interesu federacji jako całości i z poszanowaniem interesów innych kantonów.

${ }^{9}$ Konstytucja Szwajcarii, art. 54, par. 1.

${ }^{10}$ Ibidem, art. 180 i 184.
} 
czególnych aktorów. Teza ta została potwierdzona w badaniach, opublikowanych w 2004 roku (Sciarini, Fischer, Nicolet, 2004, s. 366-368). Niemniej jednak oddziaływanie legislatywy na podejmowanie określonych decyzji pozostaje nadal ważne. W szczególności w zakresie kontroli i nadzoru, poprzez zapytania, interpelacje i postulaty, kierowane pod adresem Rady Związkowej. Niektóre z nich mogą zresztą pełnić funkcję inicjującą. Najczęściej jednak parlament zaangażowany jest w sprawy zewnętrzne poprzez komisje parlamentarne, stanowiące forum współpracy i wzajemnej informacji między legislatywą a egzekutywą (Lüthi, 1999, s. 147-148). Ponadto parlament ma obowiązek zatwierdzania większości umów międzynarodowych oraz prawo do dostępu do informacji. Z tego ostatniego posłowie korzystają coraz chętniej, z uwagi na rosnące znaczenie polityki zagranicznej, w tym również wzrost oddziaływania integracji na wiele aspektów funkcjonowania państwa (Linder, 1999, s. 192).

Podsumowując, należy pamiętać, iż parlament pozostaje istotnym aktorem procesu decyzyjnego, wypełniając jednakże swoją rolę niekoniecznie bezpośrednio, tj. w ramach wykonywania konstytucyjnie określonych kompetencji - zatwierdzania umów międzynarodowych, lecz częściej pośrednio, poprzez oddziaływanie na egzekutywę, w ramach komisji parlamentarnych lub grup eksperckich, w skład których często wchodzą parlamentarzyści ${ }^{11}$.

W szwajcarskim systemie politycznym szczególnie istotnym aktorem procesu decyzyjnego jest suweren, czyli społeczeństwo, które za pomocą różnych instrumentów demokracji bezpośredniej - inicjatywy lub referendum, może istotnie wpływać na jego przebieg. Zebranie 50000 lub 100000 podpisów (dotyczy odpowiednio referendum oraz inicjatywy ludowej) pod wnioskiem o przeprowadzenie głosowania nie jest zadaniem szczególnie trudnym. Zjawisko partycypacji obywateli w podejmowaniu decyzji było już wielokrotnie przedmiotem analiz politologicznych ${ }^{12}$. Szwajcarska demokracja często stawiana jest zresztą jako wzór dla innych państw. Nie wszyscy jednakże podzielają ten entuzjazm. Zdaniem wielu badaczy referendum pełni często rolę hamulcową, uniemożliwiając forsowanie kontrowersyjnych społecznie, ale potrzebnych reform. Nierzadko wykorzystywane jest instrumentalnie przez konserwatywną opozycję parlamentarną (Linder, 1999, s. 255; Papadopoulos, 1994, s. 137) ${ }^{13}$. Z kolei inicjatywa ludowa, z zasady dająca możliwość akcentowania własnych interesów przez wszystkie grupy społeczne, może być sprawnym narzędziem pozyskania elektoratu i wzmocnienia swojej pozycji przez partie bądź ugrupowania populistyczne. Co prawda praktyka wskazuje, iż w latach

${ }^{11}$ Przykładowo propozycja włączenia Szwajcarii do strefy Schengen zaprezentowana była przez grupę ekspercką, kierowaną przez posła do Rady Narodowej - Jean-François Leuba (Wichmann, 2009). Zob. także interpelację poselską Gegen eine Schweiz als ,Insel der Unsicherheit”, http://www.parlament.ch/d/suche/seiten/geschaefte.aspx?gesch id=19933349, 24.03.2014.

${ }^{12}$ Wśród polskich opracowań, które zostały w ostatnim czasie opublikowane warto wymienić chociażby Maślak (2012, s. 119-132), Aleksandrowicz (2013, s. 71-85).

${ }^{13}$ Warto w tym miejscu jednak dodać, iż powyższej tezy nie potwierdzają badania Kriesi i Wisler. Uważają oni, iż w latach 1945-1978 referendum faktycznie wykorzystywane było najczęściej przez konserwatywną prawicę. Jednakże wykazali oni także, iż w kolejnych latach, tj. między 1979 a 1989 referendum fakultatywne znacznie chętniej wykorzystywane było przez ugrupowania z lewej strony sceny politycznej. Traktując je z kolei jako instrument nacisku na rząd i parlament na przeprowadzanie bardziej radykalnych reform (Kriesi, Wisler, 1996). 
1891-2013 relatywnie niewielka liczba propozycji zyskała niezbędną większość - ok $11 \%{ }^{14}$. Znaczenie inicjatywy ludowej należałoby jednak oceniać w kategoriach jakościowych, a nie ilościowych. Przyjęcie określonej poprawki może mieć bowiem daleko idące konsekwencje dla rozwoju relacji zewnętrznych Szwajcarii i jej wizerunku międzynarodowego. Dobrym tego przykładem jest chociażby referendum w sprawie zakazu budowy minaretów lub przeciwko masowej emigracji (podważające przyjęte przez Szwajcarię oraz Unię Europejską wzajemne regulacje). W kontekście polityki zagranicznej warto wspomnieć również o referendum obligatoryjnym, które przeprowadzane jest w przypadku możliwości wejścia Szwajcarii do ponadnarodowej organizacji (do takich zaliczamy oczywiście Unię Europejska) lub organizacji kolektywnego bezpieczeństwa ${ }^{15}$. Perspektywa przystapienia do tej ostatniej jest z uwagi na neutralność Szwajcarii mało prawdopodobna, przynajmniej w dającej się przewidzieć przyszłości.

Suweren współkształtuje zatem proces decyzyjny, jednakże należy podkreślić, iż bezpośrednie oddziaływanie obywateli dotyczy jedynie jego końcowego etapu, tj. przyjęcia lub odrzucenia określonej propozycji legislacyjnej w całości, związanej z polityką zagraniczną. Nie mają natomiast możliwości wpływania na jej kształt merytoryczny. Choć należałoby tutaj uwzględnić możliwość pośredniego oddziaływania, kiedy decydenci polityczni, mając na względzie możliwość przeprowadzenia głosowania, starają się wypracować decyzje, których prawdopodobieństwo zawetowania przez suwerena będzie jak najmniejsze. Tym bardziej, iż w kwestiach polityki zagranicznej nastroje opinii publicznej są raczej konserwatywne, sprzyjające tradycyjnym wartościom i koncepcjom. W tym sensie pole manewru decydentów politycznych pozostaje zawężone. Odważniejsze działania w polityce zagranicznej są więc często trudne do zrealizowania, zmuszając rząd do podejmowania bardziej zachowawczych decyzji. Polityka europejska jest tego najlepszym przykładem, o czym więcej w dalszej części tekstu.

Partie polityczne, jako kolejny aktor procesu decyzyjnego, oddziaływują zasadniczo nań w dwóch etapach - bezpośrednio w parlamencie oraz na etapie przedparlamentarnym, prezentując swoje stanowisko w trakcie konsultacji. W przypadku tych ostatnich ocenia się, iż realny wpływ partii jest znacznie niższy niż stowarzyszeń lub kantonów (Linder, 1999, s. 82; Landner, 1991, s. 237-239). Logika wskazywałaby zatem, iż parlament jest właściwszym forum wywierania wpływu na proces decyzyjny. Należy jednak pamiętać, iż posłowie nie są związani żadnymi instrukcjami, w związku z tym nie obowiązuje ich dyscyplina partyjna (Por. Kriele, 1977, s. 37; Müller, 1993, s. 56). Ponadto należy pamiętać, iż szwajcarski system partyjny jest bardzo sfragmentaryzowany, a pomiędzy tymi samymi partiami w poszczególnych kantonach widoczne są różnice programowe (Armingeon, 1989, s. 321-345). Nie można zatem zakładać, iż stanowisko członka rządu będzie zawsze popierane przez frakcję z której się wywodzi. Również odwrotnie, nie można domniemywać, iż członek Rady Związkowej będzie podzielał w danym procesie decyzyjnym stanowisko swojej partii.

Niemniej jednak, w kontekście niniejszej analizy, należy wskazać, iż partie polityczne coraz częściej podkreślają w swych programach wyborczych postulaty związane z ak-

\footnotetext{
${ }^{14}$ Dane według Schweizerische Bundeskanzlei, http://www.admin.ch/ch/d/pore/vi/vis $22259 . \mathrm{html}$, 5.03.2014.

${ }^{15}$ Referendum obligatoryjne przeprowadza się również w przypadku zmian konstytucji.
} 
tywnością Szwajcarii na arenie międzynarodowej. Wynika to z rosnącej zależności pomiędzy polityką wewnętrzną i zagraniczną, które wzajemnie na siebie oddziałują. Widoczne jest to zwłaszcza w polityce europejskiej. Tematy pośrednio lub bezpośrednio związane z tą problematyką zyskują coraz większą popularność, a co za tym idzie ich znaczenie dla budowy elektoratu stale wzrasta. Jaskrawym tego przykładem jest praktyka Szwajcarskiej Partii Ludowej, która zdobyła popularność właśnie na tematach związanych z integracją europejska, miejscem Szwajcarii w całym procesie, a także społecznych i gospodarczych skutkach postępującej integracji z UE. Nie będzie przesadą stwierdzenie, iż właśnie tej partii Szwajcarzy zawdzięczają fakt, iż nie są jeszcze członkami Wspólnoty.

Warta podkreślenia jest natomiast rola związków i stowarzyszeń, zwłaszcza tych, które są dobrze zorganizowane i dysponują sporymi zasobami finansowymi. Dotyczy to zwłaszcza sektora małych i średnich przedsiębiorstw. Wpływ na proces decyzyjny jest dość duży, chociażby ze względu na jego wielowymiarowość. Stowarzyszenia biorą udział na etapie przedparlamentarnym w konsultacjach, w trakcie których mogą reprezentować własne interesy i stanowisko (Kriesi, 1980, s. 674). Przedstawiciele związkowi biorą udział w spotkaniach komisji parlamentarnych lub w charakterze ekspertów w spotkaniach grup roboczych. Stowarzyszenia mogą także inicjować określone propozycje legislacyjne, wchodząc przykładowo w skład komitetów inicjatywnych. Podobnie jak partie polityczne, biorą również aktywny udział w kampanii referendalnej. Warta uwagi jest zatem ich rola opiniotwórcza ${ }^{16}$. Z uwagi na ich kluczowe znaczenie w procesie decyzyjnym często przypisuje się im rolę tzw. veto-players. Poprzez swoje wpływy i oddziaływanie na opinię publiczną mogą zadecydować o przyjęciu lub odrzuceniu nowej propozycji legislacyjnej (Fischer, 2003).

Podobnie jak w przypadku partii politycznych, znaczenie związków i stowarzyszeń w procesie decyzyjnym, dotyczącym polityki zagranicznej, wyraźnie wzrosło w ostatnim czasie. Głównie z uwagi na postępującą integrację gospodarczą, globalizację, liberalizację rynków i coraz większe zainteresowanie międzynarodową aktywnością firm szwajcarskich. Można nawet pokusić się o stwierdzenie, iż interesy sektora prywatnego muszę być w sposób szczególny uwzględniane przez decydentów politycznych. Oczywiście teza ta może zostać uznana za dość kontrowersyjną, jednakże warto pamiętać chociażby o ekonomicznych przesłankach, którymi kierował się rząd, nawiązując współpracę z EWG, a wcześniej EFTA.

Kantony mają możliwość oddziaływania na procesy decyzyjne zwłaszcza poprzez Radę Kantonalną (Vatter, 1999; Linder, 1999, s. 142-144). Aczkolwiek należy zauważyć, iż w skład izby wyższej parlamentu wchodzą osoby wybierane w wyborach powszechnych, reprezentujące interesy swojego okręgu wyborczego, a niekoniecznie kantonu jako całości ${ }^{17}$. Ponadto przedstawiciele kantonów biorą udział w konsultacjach przedparlamentarnych oraz w komisjach eksperckich. W kontekście polityki europejskiej należałoby wskazać przede wszystkim na Konferenz der Kantonsregierungen (Konferencja

${ }^{16}$ Zwłaszcza związki prasowe mają z oczywistych względów szczególny wpływ na opinię publiczną. Por. Höpflinger (1984, s. 173).

${ }^{17} \mathrm{Z}$ każdego kantonu wybieranych jest dwóch przedstawicieli, a z półkantonu po jednym. Łącznie w Radzie Kantonalnej zasiada 46 posłów. 
Rządów Kantonalnych, KdK), którą powołano do życia w 1993 roku, jako ciało o charakterze informacyjno-konsultacyjnym (Hänni, 2000). Jej głównym celem jest reprezentowanie interesów wszystkich władz regionalnych i współdecydujących o polityce Związku (Münger, 1994, s. 249). Co ważne, KdK nie jest instrumentem przeznaczonym wyłącznie do realizacji polityki europejskiej, lecz bardziej instytucją nacisku czy też oddziaływania na te obszary, które z punktu widzenia interesu kantonów mają dla nich kluczowe znaczenie (Tomczyk, 2013). Zgodnie z konstytucją władze federalne mają obowiązek konsultowania swych decyzji z KdK ${ }^{18}$. Wypracowane przez Konferencję stanowisko, w kwestiach o szczególnym dla nich znaczeniu, ma dla Związku charakter wiążący. Niektórzy badacze wskazująjednakże na relatywnie niski poziom legitymizacji wspólnego stanowiska kantonów, mając na uwadze fakt, iż decyzje podejmowane są większością głosów i rzadko spotykana jest w tym wypadku jednomyślność (Rhinow, 1998, s. 10-11). Ponadto w czerwcu 2012 r. podjęto decyzję o utworzeniu Komitetu Sterującego, jako stałego organu wymiany informacji między Związkiem a Kantonami ${ }^{19}$. Główną ideą jego powołania było wzmocnienie współpracy, celem podejmowania wspólnych, uwzględniających interesy obu stron, decyzji dotyczących szeroko rozumianej polityki europejskiej. W skład Komitetu Sterującego wchodzą przedstawiciele KdK oraz, ze strony rządowej, szefowie resortu spraw zagranicznych oraz gospodarki. Z punktu widzenia polityki zagranicznej istotne jest również, iż przedstawiciele kantonów wchodzą często w skład delegacji rządowej na negocjacje międzynarodowe ${ }^{20}$. Ponieważ w praktyce kantony są odpowiedzialne za wdrażanie postanowień umów międzynarodowych, ich opinia i interesy muszą być uwzględniane przez decydentów politycznych. Jest to zresztą jeden z elementów kultury politycznej Szwajcarii, wpisujący się w szersze pojęcie demokracji konsensualnej (Linder, 1999, s. 347).

Ta ostatnia jest niezbędnym elementem zrozumienia specyfiki podejmowania decyzji. Wymienieni wyżej różni aktorzy procesu decyzyjnego, uczestnicząc w kolejnych jego etapach wzajemnie na siebie oddziaływują, tworząc tzw. polityczną sieć - policy networks (Börzel, 1998; Henry, 2011; Knoke, 1996). Ich współpraca wynika z konieczności budowania doraźnych lub stałych koalicji, w zależności od własnych preferencji czy reprezentowanych interesów grupowych. Żaden z aktorów nie jest bowiem w stanie samodzielnie wpływać na podejmowanie określonych decyzji. Oczywiście zmiany otoczenia międzynarodowego nie pozostają bez wpływu na zachowanie aktorów na poziomie krajowym. W tym kontekście przedmiotem licznych analiz były procesy europeizacji,

\footnotetext{
${ }^{18}$ Nowelizacja konstytucji z 1999 roku wzmocniła jednakże w tym względzie pozycję kantonów. W przeciwieństwie do poprzedniej ustawy zasadniczej z 1874 roku kantony zyskały możliwość współdecydowania lub przynajmniej wyraźnego oddziaływania na decyzje polityczne Związku. Władze federalne mają konstytucyjny obowiązek uwzględnienia stanowiska kantonów w sprawach, mieszczących się w ramach ich obszarów kompetencyjnych lub dotykających ich „istotnych interesów” (Tornay, Renfer, Auer, 2006, s. 252).

${ }^{19}$ Bund und Kantone unterzeichnen Vereinbarung zum Europadialog, Medienmitteilung EDA/EVD, Bern 5.06.2012.

${ }^{20}$ Doświadczenia i efekty tej formy współpracy okazały się dla obu stron niezwykle cenne, co znalazło swe odzwierciedlenie w dokumencie podsumowującym zawarcie pierwszego pakietu Bilaterale I, opublikowanego w 1999 roku przez Radę Związkową: Botschaft des Bundesrates zur Genehmigung der sektoriellen Abkommen zwischen der Schweiz und der EG, Bern 1999, BBI nr 34, 6144-6145.
} 
które wpłynęły zarówno na sposób funkcjonowania poszczególnych instytucji, procesy jak i samą praktykę polityczną poszczególnych państw ${ }^{21}$. W przypadku Szwajcarii mamy tutaj do czynienia chociażby ze wzmocnieniem pozycji egzekutywy oraz znaczenia nieformalnych konsultacji przedparlamentarnych ${ }^{22}$. W przypadku polityki zagranicznej, rząd i jego administracja, będąc odpowiedzialnym za negocjowanie porozumień międzynarodowych i ich ostateczny kształt, ma równocześnie zdecydowanie największy dostęp do informacji i pewien rodzaj autonomii, co plasuje go w znacznie korzystniejszej pozycji niż pozostałych aktorów procesu decyzyjnego. Rola tych drugich sprowadza się jedynie do przyjęcia lub odrzucenia określonej propozycji. Należy jednak pamiętać, iż decydenci polityczni funkcjonują zawsze w warunkach tzw. gry na dwóch poziomach - two level games (Putnam, 1988), oznaczającej, iż podejmowane przez nich decyzje muszą uwzględniać uwarunkowania zewnętrzne, jak i wewnętrzne, m.in. innych aktorów na poziomie krajowym. Jest to szczególnie charakterystyczne dla małych państw o charakterze korporacyjnym, które mogą poszczycić się długą tradycją negocjacji i konsensualizmu pomiędzy państwowymi i pozapaństwowymi aktorami (Katzenstein, 1985). Dlatego też egzekutywa zmuszona jest, m.in. poprzez nieformalne konsultacje szukać takich rozwiązań, które będą społecznie akceptowalne ${ }^{23}$. W tym sensie możemy mówić nawet o wzroście wzajemnej zależności pomiędzy poszczególnymi aktorami procesu decyzyjnego.

Niektórzy badacze zauważają również, iż europeizacja sprzyja innowacyjności i forsowaniu zmian czy reform, które byłyby w innych okolicznościach trudne do realizacji (Fischer, Sciarini, 2013, s. 1484). W takim znaczeniu, iż decydenci polityczni mogą wykorzystać nowe uwarunkowania geopolityczne jako wytłumaczenie konieczności wprowadzenia pewnych zmian, warunkujących utrzymanie konkurencyjności państwa na zglobalizowanych rynkach. Jak dowodzą niektóre analizy, europeizacja wzmacnia również pozycję tych grup interesu, które czerpią szczególne korzyści z otwarcia i liberalizacji, jak chociażby nastawione na eksport podmioty sektora prywatnego (Sciarini, Fischer, Nicolet, 2004, s. 359) ${ }^{24}$. Należą one zatem do aktorów zdecydowanie popierających ideę integracji europejskiej. To ważne, biorąc pod uwagę ich duże możliwości finansowego wspierania kampanii referendalnych.

\section{Konkluzje}

Zaprezentowana pokrótce charakterystyka procesu decyzyjnego w Szwajcarii nie wyczerpuje wszystkich problemów z nim związanych, pokazuje jednak w jaki sposób należałoby analizować zachowanie państwa na arenie międzynarodowej. Przytoczone ar-

${ }^{21}$ Warto w tym kontekście wspomnieć o analizach Moravcsika, według którego europeizacja przyczynia się do zmian krajowego kontekstu prowadzenia polityki zagranicznej, poprzez zmiany w obszarze tzw. czterech I - inicjatywy, instytucji, informacji, idei (Moravcsik, 2001).

${ }^{22}$ Zob. ciekawą analizę na ten temat Sciarini, Fischer, Nicolet (2004).

${ }^{23}$ W szczególności niezbędne jest pozyskanie poparcia tzw. veto-players (Fischer, Sciarini, 2013, s. 1486).

${ }^{24}$ Warto przytoczyć tutaj badania, sugerujące, iż otwartość gospodarcza sprzyja konsensusowi na poziomie krajowym (Katzenstein, 1984, 1985). 
gumenty świadczą o złożoności i wielowymiarowości całego procesu. Dlatego też trudno oceniać relacje międzynarodowe wyłącznie z perspektywy teorii realizmu, traktującego państwo jako spójną całość, a stosunki między państwami, analizując wyłącznie z perspektywy określonych działań, będących reakcją na bodźce płynące z otoczenia. Trudno nie zgodzić się zatem z postulatem konieczności prowadzenia badań nad stosunkami międzynarodowymi z perspektywy wielopłaszczyznowej, analizującej nie tylko decyzje państwa jako całości, ale również, a może przede wszystkim, przy uwzględnieniu stanowisk oraz pozycji i siły oddziaływania poszczególnych instytucji, grup interesu oraz jednostek. Ich wzajemnych zależności, sposobu funkcjonowania i wpływu na otoczenie.

Postulat ten wydaje się wyjątkowo aktualny przy analizowaniu procesów integracyjnych. Ich bezprecedensowy charakter i wielopłaszczyznowość wymusza uwzględnianie wielu zmiennych. Integracja europejska, zgodnie z teorią funkcjonalizmu, jest zjawiskiem obejmującym coraz szersze obszary funkcjonowania państwa, a co za tym idzie dotykająca znacznie szersze spectrum społeczne, niż w przypadku zwykłej współpracy bilateralnej. Jest to jeden z powodów, dla których docelowy model integracyjny jest na obecnym etapie trudny do przewidzenia. $Z$ jednej strony mamy do czynienia ze zjawiskiem rozlewania się (spill-over), a więc rozszerzenia współpracy na coraz to nowe dziedziny, co sugeruje zresztą liniowy postęp w kierunku wyższego stopnia integracji i większego wpływu czynników ponadnarodowych (Zielińska-Głębocka, 1999). Z drugiej, z okresowymi kryzysami i zakłóceniami dynamiki integracyjnej, w postaci wzrostu nastrojów narodowych, eurosceptycznych i zahamowania, a nawet odwrócenia tych procesów (Wessels, 1997).

Dlatego też warto, zastanawiając się nad modelem rozwoju integracji, wziąć także pod uwagę uwarunkowania wewnętrzne, na poziomie poszczególnych państw, które zadecydowały o takiej a nie innej formie współpracy. W przypadku Szwajcarii, wiele decyzji podjętych w zakresie polityki europejskiej warunkowanych było wyjątkowym charakterem procesu decyzyjnego, determinowanego specyfiką demokracji konsensualnej. Wybór dotychczasowej formy współpracy, opartej na rozwiązaniach bilateralnych był wynikiem kompromisu, zawartego pomiędzy kluczowymi grupami interesu i elitą polityczną. W żadnym wypadku nie można oceniać go w kategoriach jednostronnej i autonomicznej decyzji, podjętej przez szwajcarskie władze. W tym sensie integrację należałoby rozpatrywać nie tyle jako stan, lecz proces, którego zrozumienie i próba wytłumaczenia, a nawet antycypacji możliwa jest tylko przy uwzględnieniu problemów instytucjonalnych, podkreśleniu roli grup interesu, opinii publicznej, elit społecznych i politycznych oraz innych krajowych aktorów, a nawet elementów socjopsychologicznych.

\section{Bibliografia}

Aleksandrowicz M. (2013), Miejsce inicjatywy ludowej $w$ konsensualizmie szwajcarskim, w: Współczesna demokracja bezpośrednia : dialog polsko-szwajcarski, red. B. Wiśniewska-Paź, Aureus, Kraków.

Armingeon K. (1989), Sozialdemokratie am Ende? Die Entwicklung der Macht sozialdemokratischer Parteien im internationalen Vergleich 1945-1988, „Österreichische Zeitschrift für Politikwissenschaft" $18, \mathrm{nr} 4$. 
Börzel T. A. (1998), Organizing Babylon - on the different conceptions of policy networks, „Public Administration”, $\mathrm{nr}$ 76, s. 253-273.

Bundesverfassung der Schweizerische Eidgenossenschaft vom 18. April 1999, SR 101.

Byman D. L., Pollack K. M. (2001), Let us now praise great men: Bringing the statesman back In, „International Security", vol. 25, $\mathrm{nr} 4$.

Fischer A. (2002), Wirtschaftsbranche, Gewerkschaften und Interessengegensätze der Arbeitgeber: Der Fall der flankierenden Massnahmen zur Personenfreizügigkeit, „Swiss Political Science Review", nr 8(3/4), s. 85-100.

Fischer A. (2003), Vetospieler und die Durchsetzbarkeit von Side-Payments, „Swiss Political Science Review", nr 9(2), s. 27-58.

Fischer A., Nicolet S., Sciarini P. (2002), Europeanisation of a Non-EU Country: The Case of Swiss Immigration Policy, „West European Politics”, vol. 25, nr 4.

Fischer M., Sciarini P. (2013), Europeanization and the inclusive strategies of executive actors, ,Journal of European Public Policy", vol. 20, nr 10.

Goetschel L., Bernath M., Schwarz D. (2002), Schweizerische Aussenpolitik: Grundlagen und Möglichkeiten, Verlag Neue Zürcher Zeitung, Zürich.

Gillespie P. (1996), Models of Integration, w: Constitution-Building in the European Union, red. B. Laffan, Institute of European Affairs, Dublin.

Hänni P. (2000), Schweizerischer Föderalismus und europäische Integration, Schulthess, Zürich.

Henry A. D. (2011), Ideology, power, and the structure of policy networks, „Policy Studies Journal”, nr 39(3), s. 361-383.

Höpflinger F. (1984), Verbände, w: Handbuch Politisches System der Schweiz. Band 2: Strukturen und Prozesse, Bern, s. 163-188.

Jervis R. (1988), Realism, game theory, and cooperation, „World Politics”.

Kantonsregierungen (red.) (2006), Zwischen EU-Beitritt und bilateralem Weg: Überlegungen und Reformbedarf aus kantonaler Sicht, Schulthess, Zurich-Basel-Genf, s. 252.

Katzenstein P. J. (1984), Corporatism and Change. Austria, Switzerland, and the Politics of Industry, Cornell University Press, Ithaca-London.

Katzenstein P. (1985), Small States in World Markets, Cornell University Press, New York-Ithaca.

Knoke D., Pappi F. U., Broadbent J., Tsujinaka Y. (1996), Comparing Policy Networks - Labor Politics in the U.S., Germany, and Japan, Cambridge University Press, Cambridge.

Kriele M. (1977), Legitimitätsprobleme der Bundesrepublik, München.

Kriesi H. (1980), Entscheidungsstrukturen und Entscheidungsprozesse in der Schweizer Politik, Frankfurt.

Kriesi H., Trechsel A. H. (2008), The Politics of Switzerland: Continuity and Change in a Consensus Democracy, University Press, Cambridge.

Kriesi H., Wisler D. (1996), Social movements and direct democracy in Switzerland, „European Journal of Political Research", nr 30, s. 19-40.

Layne A., Schwarz B. (1993), American hegemony - Without an enemy, „Foreign Policy”, vol. 92.

Landner A. (1991), Politische Gemeinden, kommunale Parteien und lokale Politik. Eine empirische Untersuchung in den Gemeinden der Schweiz, Zürich.

Linder W. (1999), Direkte Demokratie, w: Handbuch der Schweizer Politik, red. U. Klöti, P. Knoepfel, H. Kriesi, W. Linder, Y. Papadopoulos, Zürich.

Lüthi R. (1999), Parlament, w: Handbuch der Schweizer Politik, red. U. Klöti, P. Knoepfel, H. Kriesi, W. Linder, Y. Papadopoulos, Zürich.

Maślak E. (2012), Instytucje demokracji bezpośredniej w szwajcarskim modelu demokracji konsensualnej, „Politeja”, nr 3(21), s. 119-132. 
Mearsheimer J. (1995), The false promise of international institutions, „International Security”, vol. 19 , nr 3, s. 5-49.

Medrano J. D. (2012), The Limits of European Integration, „Journal of European Integration”, vol. 34, nr 2, s. 191-204.

Moravcsik A. (2001), The Choice for Europe: Social Purpose and State Power from Messina to Maastricht, Cornell University Press, Ithaca.

Moravcsik A. (1993), Preferences and Power in the European Community: A Liberal Intergovernmentalist Approach, „Journal of Common Market Studies”, vol. 31, nr 4.

Morgenthau H. (2005), Politics among nations: the struggle for power and peace, McGraw-Hill Higher Education, 7 edition.

Müller J. P. (1993), Demokratische Gerechtigkeit: eine Studie zur Legitimität politischer und rechtlicher Ordnung, München.

Münger B. (1994), Die Konferenz der Kantonsregierungen, w: Die Kantone und Europa, Freiburghaus D., Bern.

Neidhart L. (1970), Plebiszit und pluralitäre Demokratie. Eine Analyse der Funktion des schweizerischen Gesetzesreferendums, Bern.

Papadopoulos Y. (1994), Les votations federales comme indicateur de soutien aux autorities, w: Elites politiques et peuple en Suisse, red. Y. Papadopoulos, Lausanne, s. 113-160.

Putnam R. D. (1988), Diplomacy and domestic politics: the logic of two level games, „International Organization", vol. 42, nr 3, s. 427-460.

Rhinow R. (1998), Aus der Sicht eines Parlamentariers, w: Die Beteiligung der Kantone an der Aussenpolitik, NFP 42 Working Paper nr 3, s. 8-14.

Rhinow R., Huber-Hotz A. (1996), The future of the Political System, w: The new Switzerland: Problems and Policies, red. R. Kieser, K. Spillmann, Palo Alto, s. 16-31.

Sciarini P., Fischer A., Nicolet S. (2004), How Europe hits home: evidence from the Swiss case, „Journal of European Public Policy", vol. 11, nr 3, s. 353-378.

Schnur A. R. (2000), Agieren oder Reagieren? Aussenpolitische Entscheidungsprozesse in Bundesrat und Bundesverwaltung, Verlag Ruegger, Zürich.

Stubb A. C-G. (1996), A Categorization of Differentiated Integration, ,Journal of Common Market Studies", vol. 34, nr 2.

Tomczyk M. (2012), Berno-Bruksela. Problemy $i$ wyzwania we wzajemnych relacjach, w: Niemcy, Austria, Szwajcaria. Wyzwania z przełomu XX/XXI w., red. E. Kuczyński, M. Tomczyk, Łódź.

Tomczyk M. (2013), Polityka Szwajcarii wobec Unii Europejskiej, Łódź.

Tornay B., Renfer I., Auer A. (2006), Die Kantone zwischen EU-Beitritt und bilateralen Weg: Direkte Demokratie, Mitwirkung an der Europapolitik und Umsetzung, w: Zwischen EU-Beitritt und bilateralem Weg: Überlegungen und Reformbedarf aus kantonaler Sicht, red. Konferenz der Kantonsregierungen, Schulthess, Zurich-Basel-Genf.

Vatter A. (1999), Föderalismus, w: Handbuch der Schweizer Politik, red. U. Klöti, P. Knoepfel, H. Kriesi, W. Linder, Y. Papadopoulos, Zürich.

Voss J. F., Dorsey E. (1992), Perception and international relations: An overview, w: Political psychology and foreign policy, red. E. Singer, V. Hudson, Boulder, s. 3-33.

Waltz K. (1979), Theory of international politics, Addison-Wesley.

Wessels W. (1997), An Ever Closer Fusion? A Dynamic Macropolitical View on Integration Processes, „Journal of Common Market Studies”, vol. 35, nr 2.

Zielińska-Głębocka A. (1999), Dynamika Unii Europejskiej w świetle teorii integracji, „Studia Europejskie", vol. 3. 


\title{
Decision-making process as an important element of theoretical analysis of European integration. The Swiss case
}

\begin{abstract}
Summary
For many years we have been witnessing scientific disputes between researchers, who are involved in modelling the development of European integration. Many of them have suggested moving its analysis from the level of whole system to the level of individual states, in order to justify better the motives of integration and its various forms. The understanding of the behaviour of the states on the international arena, including actions taken towards other actors - also states or organizations, is not possible without explaining the nature and character of the decision-making processes. Therefore, this article is focusing on the decision-making process as an important element in the analysis of European integration. Switzerland is used here as a reference point, a country formally remaining outside of the EU, but practically strongly integrated with the Community. The presented characteristics of decision-making process in Switzerland shows which elements should be taken into account when analysing the behaviour of states on the international arena, and why its proper analysis can be used to clarify the alternative forms of European integration. Thus, providing a contribution to the discussion on its theoretical aspects.
\end{abstract}

Key words: European integration, Switzerland, decision-making process, foreign policy 
